\title{
Age, growth and mortality in the giant snail Adelomelon beckii (Broderip 1836) on the Argentinean shelf
}

\author{
Florencia Arrighetti ${ }^{\mathrm{a}, *}$, Thomas Brey ${ }^{\mathrm{b}}$, Andreas Mackensen ${ }^{\mathrm{b}}$, Pablo E. Penchaszadeh ${ }^{\mathrm{a}}$ \\ a CONICET, Museo Argentino de Ciencias Naturales, Av Angel Gallardo 470, (1405) and Facultad de Ciencias Exactas y Naturales, UBA, Buenos Aires, Argentina \\ ${ }^{\mathrm{b}}$ Alfred Wegener Institute for Polar and Marine Research, Bremerhaven, Germany
}

\section{A R T I C L E I N F O}

Article history:

Received 25 August 2009

Received in revised form 1 September 2010

Accepted 6 October 2010

Available online 14 October 2010

\section{Keywords:}

Marine Gastropod

Age

Growth

Mortality

Production

Fisheries Management

\begin{abstract}
A B S T R A C T
The marine subtidal volutid snail Adelomelon beckii was studied in order to obtain their population dynamics, particularly on growth, age, mortality and production. Stable oxygen isotope ratios confirmed semiannual formation of internal growth marks. A von Bertalanffy growth model fitted 308 size-at-age data pairs. A. beckii potential lifespan in Mar del Plata (Argentina) region is 29 years, being rather long lived compared to other large gastropods. Total mortality $Z$ and natural mortality $M$ were calculated to be $0.210 \mathrm{y}^{-1}$ and $0.081 \mathrm{y}^{-1}$ respectively. Fishing mortality $F$ amounts to $0.129 \mathrm{y}^{-1}$ corresponding to an exploitation rate $E$ of 0.614 , a value much beyond the optimum rate of 0.427 . The current exploitation regime will be unsustainable in the long run unless a proper management approach establishes.
\end{abstract}

Crown Copyright (c) 2010 Published by Elsevier B.V. All rights reserved.

\section{Introduction}

Adelomelon beckii is an endemic volutid in the southwestern Atlantic Ocean, distributed from Espíritu Santo (Brazil) to Tierra del Fuego (Argentina), that inhabits sandy bottoms between 30 and $70 \mathrm{~m}$ water depth (Weaver and du Pont, 1970). It is one of the largest benthic carnivores in the Mar del Plata area, often exceeding $40 \mathrm{~cm}$ in shell length. For several years, A. beckii has been fished just as bycatch by fishing trawlers, but recently the snail became a direct target of artisanal fishermen, apparently throughout its area of occurrence. Its large and attractive shell is sold in local and international markets and its muscular foot represents a sea food delicatessen. Despite its impressing size and its increasing significance as a fishery resource, surprisingly little is known about the biology of $A$. beckii and its role in the ecosystem. There have been studies on ultrastructural aspects of reproduction (Giménez et al., 2009; Arrighetti and Giménez, 2010), and a description of its reproductive cycle and size at first sexual reproduction (Arrighetti and Penchaszadeh, 2010a, b).

The objective of this study is to gain knowledge on the population dynamics of $A$. beckii, particularly on growth and mortality, in order to establish a baseline for future management of this valuable resource.

\footnotetext{
* Corresponding author. Tel.: + 5411 45763300x266.

E-mail address: flora@bg.fcen.uba.ar (F. Arrighetti).
}

\section{Materials and methods}

\subsection{Sampling}

Specimens of $A$. beckii were collected during commercial bottom trawling off Mar del Plata City, Argentina ( $38^{\circ} 20^{\prime} \mathrm{S}, 57^{\circ} 3^{\prime} \mathrm{W}$ ) between 30 and $60 \mathrm{~m}$ water depth during April 2005 to March 2007. The boats employed a bottom trawl with $15 \mathrm{~m}$ mouth opening and $42 \mathrm{~mm}$ mesh size in the cod end. The area is characterized by predominantly southerly currents. Water temperature ranges between 9 and $17{ }^{\circ} \mathrm{C}$ seasonally and salinity is rather constant at 35 (Guerrero and Piola, 1997). Animals collected from the trawls were taken to the laboratory, where the shell was separated from the soft body. We measured shell length $(S L)$ and shell width $(S W)$ with a vernier caliper to the nearest millimeter and spiral growth trajectory $(S G)$ with a thread to the nearest millimeter. Shell-free wet mass (SFWM) was determined to the nearest $1 \mathrm{~g}$. The relationships between these morphometric parameters were described by linear regression.

\subsection{Growth and age}

For the analysis of the internal growth band pattern, the shells of 10 individuals were cut along the whorls following the spiral growth trajectory from the apex to the posterior end of the aperture (Fig. 1a). The cut surface was ground with sandpaper, using grits of P400, P1200, P2400 and P4000 grade and subsequently polished using a $1 \mu \mathrm{m}$ polycrystalline diamond suspension. The polished shell cuts were examined by stereomicroscope. Visible internal growth marks were 


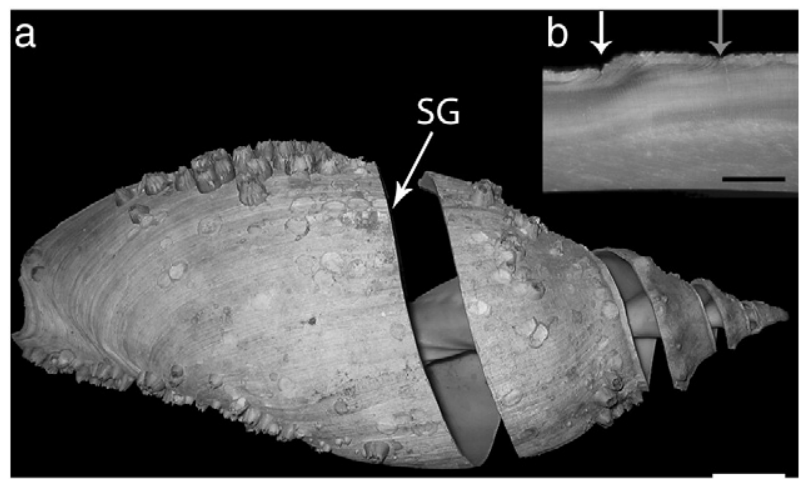

Fig. 1. Adelomelon beckii. a. Picture showing the spiral growth trajectory (SG), along which the samples for oxygen isotopes were taken. Scale bar $4 \mathrm{~cm}$. b. Internal growth marks under stereoscopic microscope showing winter marks (white arrow) and summer marks (grey arrow). Scale bar $500 \mu \mathrm{m}$.

identified in both halves of the shell and the corresponding growth trajectory length $S G_{i}$ from the apex to mark $i$ was measured.

Periodicity of growth band formation was evaluated by means of stable oxygen isotope analysis $\left(\delta^{18} \mathrm{O}\right.$, ratio of isotopes ${ }^{16} \mathrm{O}$ and $\left.{ }^{18} \mathrm{O}\right) . \delta^{18} \mathrm{O}$ in biogenic calcium carbonate structures is inversely proportional to temperature during shell deposition. This relation is nearly linear between $5^{\circ}$ and $30^{\circ} \mathrm{C}$, as demonstrated empirically by Epstein and Lowenstam (1953) and Epstein et al. (1953). Therefore, a mollusc shell from an environment with rather constant salinity and a distinct annual temperature cycle will show an oscillating pattern of $\delta^{18} \mathrm{O}$ along the major growth axis (see Bigatti et al., 2007; Cledón et al., 2005; Giménez et al., 2004 for gastropod examples).

Two representative specimens, one female of $383 \mathrm{~mm}$ (ind. 1) and one male of $370 \mathrm{~mm} \mathrm{SL}$ (ind. 2) were used for stable isotope analysis. We collected carbonate samples ( $\pm 50 \mu \mathrm{g}$ each) from the central shell layer along the $S G$ by means of a dental drill (bit size $0.5 \mathrm{~mm}$ ) at a sample-to-sample distance of about $1 \mathrm{~mm}$ (430 samples from ind. 1 and 320 samples from ind. 2 , respectively). $\delta{ }^{18} \mathrm{O}$ was determined in the stable isotope laboratory of the Alfred Wegener Institute with a Finnigan MAT251 mass spectrometer coupled to an automatic carbonate preparation device. The results were reported in $\delta$-notation versus VPDB (Vienna Pee Dee belemnite) standard calibrated via NIST 19 (National Institute of Standards and Technology isotopic reference material 19). The precision of measurements was better than $\pm 0.08 \%$ 。 for $\delta^{18} \mathrm{O}$ based on repeated analysis of a laboratory-working standard over a one-year period. $\delta^{18} \mathrm{O}\left(d^{18} O_{c}\right)$ values were converted into water temperature by the paleotemperature equation of Epstein et al. (1953), as modified by Craig (1965) and Anderson and Arthur (1983):

$T\left({ }^{\circ} \mathrm{C}\right)=16.000-4.140^{*}\left(d^{18} O_{c}-d^{18} O_{w}\right)+0.130^{*}\left(d^{18} O_{c}-d^{18} O_{w}\right)^{2}$

Sea water $\delta^{18} \mathrm{O}\left(d^{18} \mathrm{O}_{w}\right)$ was estimated at $-0.30 \%$ from the gridded data (version 1.1) of LeGrande and Schmidt (2006), see also the corresponding NASA website http://data.giss.nasa.gov/o18data).

Visual shell marks coinciding with $\delta{ }^{18} \mathrm{O}$ peaks were interpreted as winter growth marks, and the distance between two subsequent winter growth marks as the annual shell increment (see later discussion for additional summer growth marks). Thus, we interpreted each winter growth mark $i$ and its corresponding shell growth trajectory length $S G_{i}$ as one size-at-age data pair. $S G_{i}$ was translated into shell length $S L_{i}$ by means of the linear relationship between the two parameters. The iterative non-linear Newton algorithm was used to fit a growth model to the size-at-age data. The specialised von Bertalanffy growth model was found to fit the data best:

$S L_{t}=S L_{\infty} *\left(1-e^{-K *\left(t-t_{0}\right)}\right)$ where $S L_{\infty}$ is asymptotic shell length, $K$ is the body growth coefficient, $t$ is age and $t_{0}$ is theoretical age at which length equals zero. Overall growth performance was estimated by the index

$P=\log \left(K^{*} S L_{\infty}^{3}\right)$

and displayed in the form of an auximetric grid of $\log (K)$ versus $\log$ $\left(S L_{\infty}^{3}\right)$, as described by Moreau et al. (1986) and Pauly et al. (1994).

\subsection{Production}

Individual somatic production was calculated by the mass-specific growth rate method according to Brey (2001) from the size-frequency distribution, the size-body function and the growth model parameters:

$P_{j}=B M_{j}^{*} G_{j}$

where $B M_{j}$ is the mean individual body mass at size $j$ and $G j$ is the annual mass specific growth rate at size $j$ as calculated by:

$G_{j}=b^{*} K^{*}\left(S L_{\infty} / S L_{j}-1\right)$

Smaller size classes are likely to be undersampled due to the selectivity of the commercial bottom trawl, thus population production $(P)$ and production-to-biomass ratio $(P / B)$ based on size distribution were not calculated.

\subsection{Mortality, yield per recruit and exploitation rate}

We presumed that mortality in A. beckii can be described by the single negative exponential mortality model and used the corresponding size-converted catch curve (Pauly, 1984a, b) to estimate total mortality rate $Z\left(\mathrm{y}^{-1}\right)$,

$N_{j} / \Delta t_{j}=N_{0}^{*} e^{-Z t i}$

where $N_{j}$ is number in size classes $j, \Delta t_{j}$ is time required to grow through this size class $j$, and $t_{j}$ is age at midsize of size class $j$. Natural mortality rate $M$ was estimated by means of an empirical model that relates $P / B$ ratio to maximum age $t_{\max }(\mathrm{y})$, maximum body mass $B M_{\max }(\mathrm{kJ})$ and mean water temperature $T$ (Kelvin) in unexploited benthic populations (Brey 1999, 2001). If growth can be described by the von Bertalanffy model and mortality by the single negative exponential model, mortality rate $M$ and $P / B$ ratio are equivalent (Allen, 1971), hence:

$$
\begin{aligned}
\log (M)= & 1.672+0.993^{*} \log \left(1 / t_{\max }\right)-0.035^{*} \log \left(B M_{\max }\right) \\
& -300.447 / T ; N=901, r^{2}=0.880
\end{aligned}
$$

Maximum age and body mass were inferred from the largest animal through the growth model and the size-mass relationship (applying the conversion factor $3.818 \mathrm{~kJ} / \mathrm{gWM}$, average for Gastropoda, Brey, 2001).

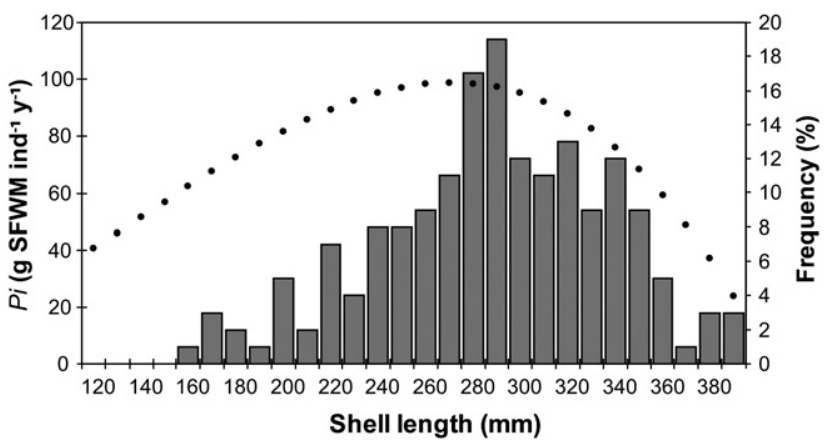

Fig. 2. Size-frequency distribution of $A$. beckii $(N=202)$ from Mar del Plata area in the years 2005-2007. Superimposed dotted line indicates individual somatic production $P_{i}$ ( $g$ shell-free wet mass year ${ }^{-1}$ ) per size class. 
Fishing mortality $F$ and exploitation rate $E$ were computed by

$F=Z-M$, and $E=F / Z$

A selection curve giving the probability of capture $P C_{J}$ per size class $j$ was computed by a procedure outlined by Pauly (1984a,b). Yield per recruitment was computed by the Beverton and Holt (1964) model, from which a predicted value for optimum exploitation rate was also obtained.

\section{Results}

The 202 individuals collected ranged from 160 to $390 \mathrm{~mm}$ shell length (Fig. 2). Shell-free wet body mass ranged from 170 to $2720 \mathrm{~g}$ and was related to $S L$ by:

$\log (\mathrm{SFWM})=-4.523+3.025^{*} \log (\mathrm{SL}) ;\left(\mathrm{g}-\mathrm{mm} ; r^{2}=0.835 ; N=202\right)$

$S L$ was linearly related to $S G$, the distance from the apex along the growth trajectory to the aperture of the shell, by:

$S L=16.197+0.499 * S G \quad\left(\mathrm{~mm}-\mathrm{mm} ; r^{2}=0.989 ; N=45\right)$

Overall sex ratio is 2.07 (see Arrighetti and Penchaszadeh, 2010a).

\subsection{Age and growth}

The $\delta{ }^{18} \mathrm{O}$ profiles showed a distinct oscillating pattern in both shells (Fig. 3). The average range of $-0.5 \%$ o to $+1.7 \%$ 。 $\delta{ }^{18} \mathrm{O}$ corresponds to a temperature range of about $8.2^{\circ} \mathrm{C}$ to $16.8{ }^{\circ} \mathrm{C}$.

Almost all $\delta^{18} \mathrm{O}$ maxima (corresponding to temperature minima) coincide with a shell growth mark, i.e. one growth mark is formed each winter. A second shell growth mark is formed each year around the time of maximum temperature, except during the first eight years and four years of life in ind. 1 and ind. 2, respectively (stippled lines in Fig. 3). The shell growth marks formed in winter, however, are much more conspicuous than those formed during summer (Fig. 1b).

The von Bertalanffy growth model

$S L_{t}=405.43^{*}\left(1-e^{-0.098 *(t-0.733)}\right) ; N=308, r^{2}=0.967$

fitted best the 308 size-at-age data pairs obtained from the 10 specimens analysed (Fig. 4). Overall growth performance of $A$. beckii (index $P=6.81$ ) is highest among commercially exploited gastropod species, but in the range of values found in other large gastropod species studied (Fig. 5). Individual somatic production $P_{j}$ increased with size $j$ up to a maximum of $98.7 \mathrm{~g}$ SFWM year $^{-1}$ at $270 \mathrm{~mm} \mathrm{SL}$ and decreased again towards larger sizes (Fig. 1).

Total mortality rate $Z$ of $A$. beckii amounted to $0.210 \mathrm{y}^{-1}$ (95\% confidence range \pm 0.053 , Fig. 6). Natural mortality rate $M$ was estimated at 0.081 (95\% confidence range 0.080-0.103), with $t_{\max }=34 \mathrm{y}($ at $390 \mathrm{~mm} \mathrm{SL}), B M_{\max }=10385 \mathrm{~kJ}(2720 \mathrm{~g} \mathrm{SFWM})$ and
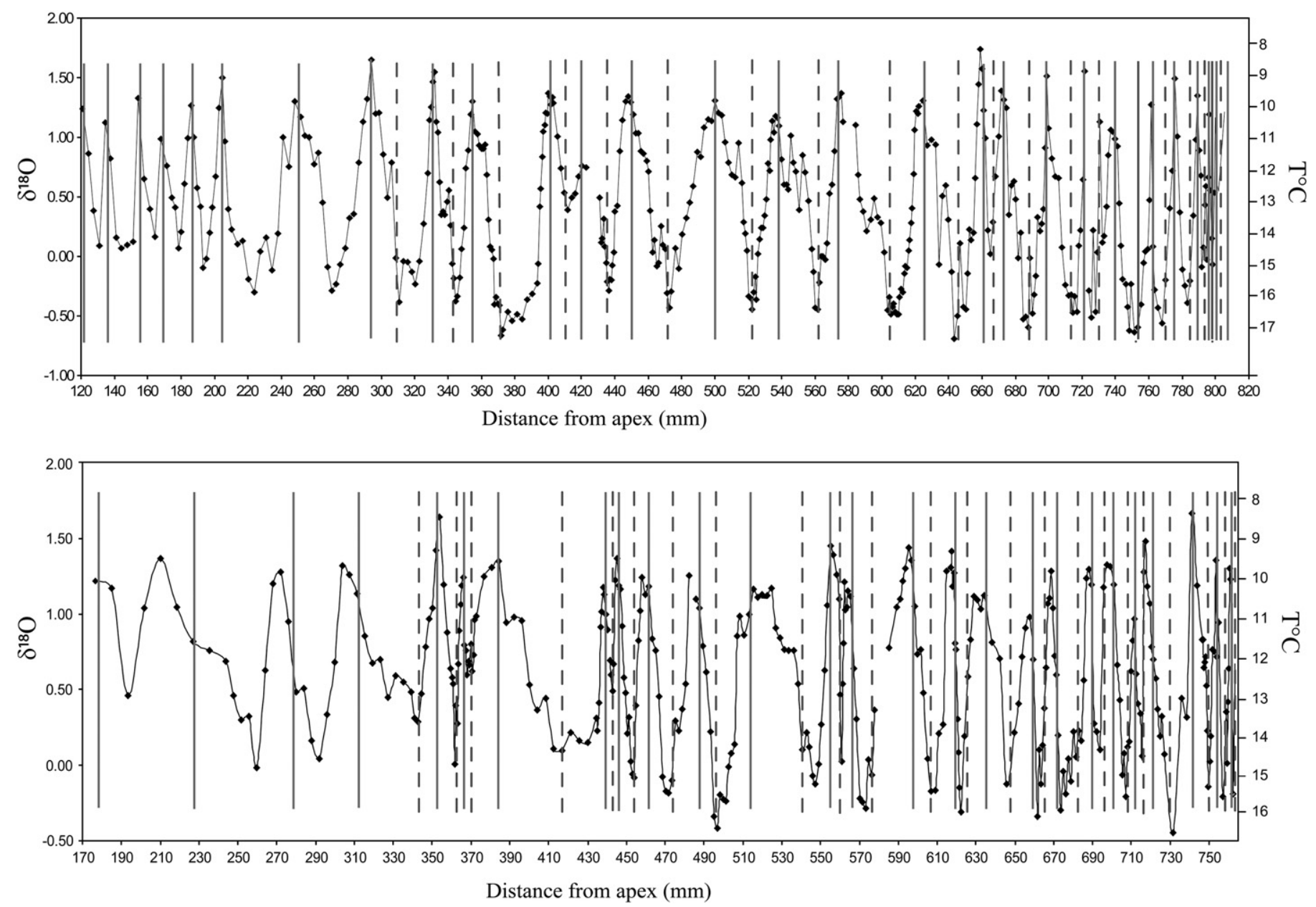

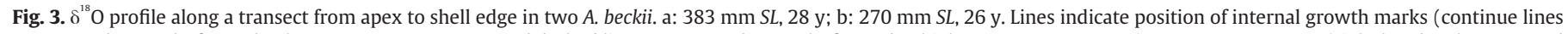

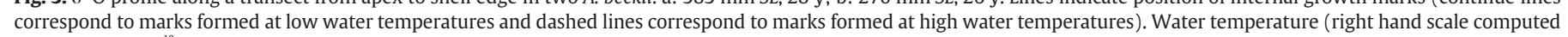
from carbonate $\delta^{18} \mathrm{O}$ by the paleotemperature equation of Epstein et al. (1953), see text for details. 


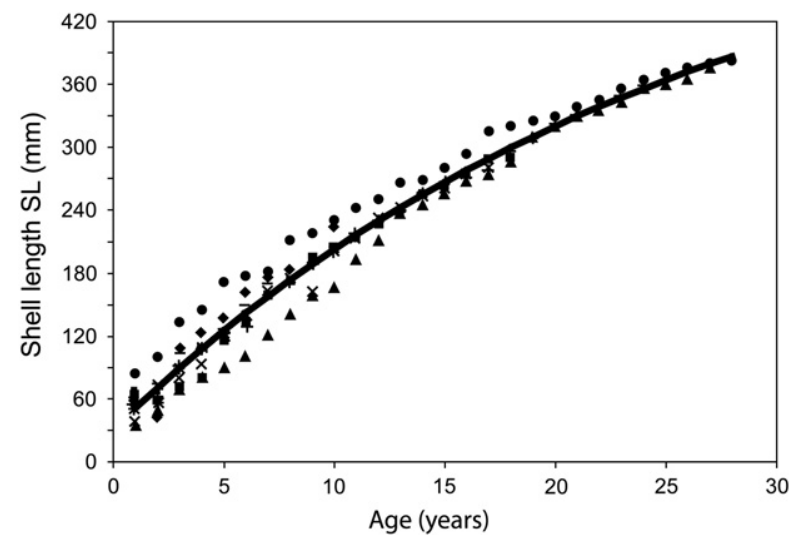

Fig. 4. Adelomelon beckii. Von Bertalanffy growth curve for Adelomelon beckii. $S L=405.43^{*}\left(1-e^{-0.098 *(t-0.733)}\right) ; r^{2}=0.967 ; N=308$ size-at-age data pairs obtained from the 10 specimens.

$T=286 \mathrm{~K}$. Accordingly, fishing mortality $F$ amounts to $0.129 \mathrm{y}^{-1}$ and exploitation rate $E$ to 0.614 . Fig. 7a shows the selection curve for the currently applied sampling technique. Specimens under $160 \mathrm{~mm}$ are not caught at all, probability of capture attains $50 \%$ at $221 \mathrm{~mm} \mathrm{SL}$ and $100 \% \geq 270 \mathrm{~mm} S L$. The optimum exploitation rate is estimated at 0.427 (Fig. 7b).

\section{Discussion}

\subsection{Stable oxygen ratios}

The average annual temperature range inferred from the $\delta^{18} \mathrm{O}$ range in the shell of $A$. beckii, $8.2^{\circ} \mathrm{C}$ to $16.8^{\circ} \mathrm{C}$, coincides with the reported instrumental range of 9 to $17^{\circ} \mathrm{C}$ seasonally (Guerrero and Piola, 1997), i.e. shell $\delta^{18} \mathrm{O}$ reflects the seasonal temperature pattern quite well. Thus, the distinct shell mark at each $\delta{ }^{18} \mathrm{O}$ maximum indicates a slow down or even halt of shell growth during winter, as observed in other large gastropod species (Bigatti et al., 2007; Cledón et al., 2005; Giménez et al., 2004). The second, weaker growth mark in the shell of $A$. beckii is formed during summer, albeit only beyond a certain age (Fig. 3 ). Such a "second" annual band has not yet been reported from other gastropods, but from some bivalves, where it coincides with the annual reproduction event (e.g. Salzwedel, 1980). We presume the same cause for the summer growth band in A. beckii, because it does not show in the early, most likely pre-maturity years, and it coincides with the time of reproductive activity (Arrighetti and Penchaszadeh, 2010a).

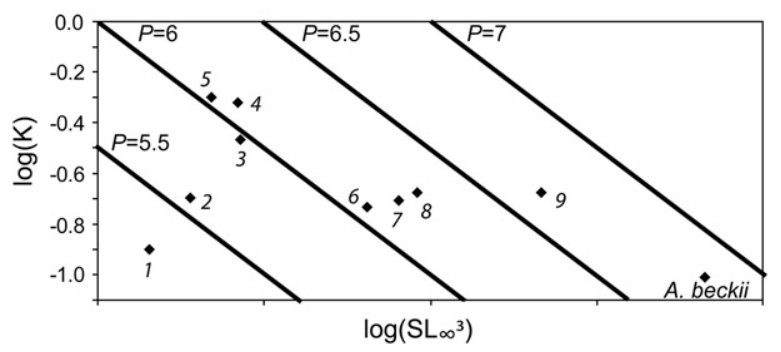

Fig. 5. Auximetric grid comparing growth performance in commercial exploited marine gastropod species. Growth performance index $P=\log \left(K^{*} \mathrm{SL}_{\infty}^{3}\right)$. 1: Buccinum undatum (Santarelli and Gros, 1985); 2: Buccinum undatum (Kideys, 1996); 3: Haliotis ruber (Shepherd and Hearn, 1983); 4: Haliotis laeviegata (Shepherd and Hearn, 1983); 5: Concholepas concholepas (Rabí and Maraví, 1997); 6: Adelomelon brasiliana (Cledón et al., 2005); 7: Odontocymbiola magellanica (Bigatti et al., 2007); 8: Zidona difresnei (Giménez et al., 2004); 9: Strombus gigas (De Jesús-Navarrete, 2001).

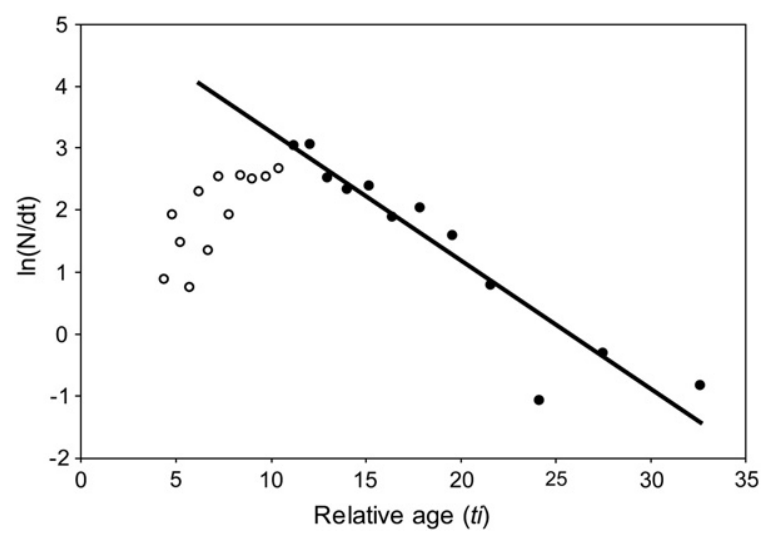

Fig. 6. Size-converted catch curve based on the size-frequency distribution (Fig. 2) and the growth function (Fig. 4) of A. beckii. Dots: data included in regression; circles: data excluded from regression. $\ln (\mathrm{N} / \mathrm{dt})=-0.207 t i+5.354 ; r^{2}=0.88 ; 95 \%$ confidence range of slope $= \pm 0.053$.

\subsection{Age and growth}

According to the isotopic data and the internal growth marks observed we can infer that $A$. beckii reaches 28 years at $380 \mathrm{~mm} \mathrm{SL}$. Potential lifespan in Mar del Plata region is $>29$ years, as the largest individuals recorded so far had $390 \mathrm{~mm} \mathrm{SL}$. This is rather long lived compared to other large gastropods, in particular other species of the same family, e.g. Zidona dufresnei (17 years, Giménez et al., 2004), Adelomelon brasiliana (20 years, Cledón et al., 2005) and Odontocymbiola magellanica (20 years, Bigatti et al., 2007). Despite this high maximum age, growth is comparatively rapid, as indicated by the high overall growth performance (Fig. 5).
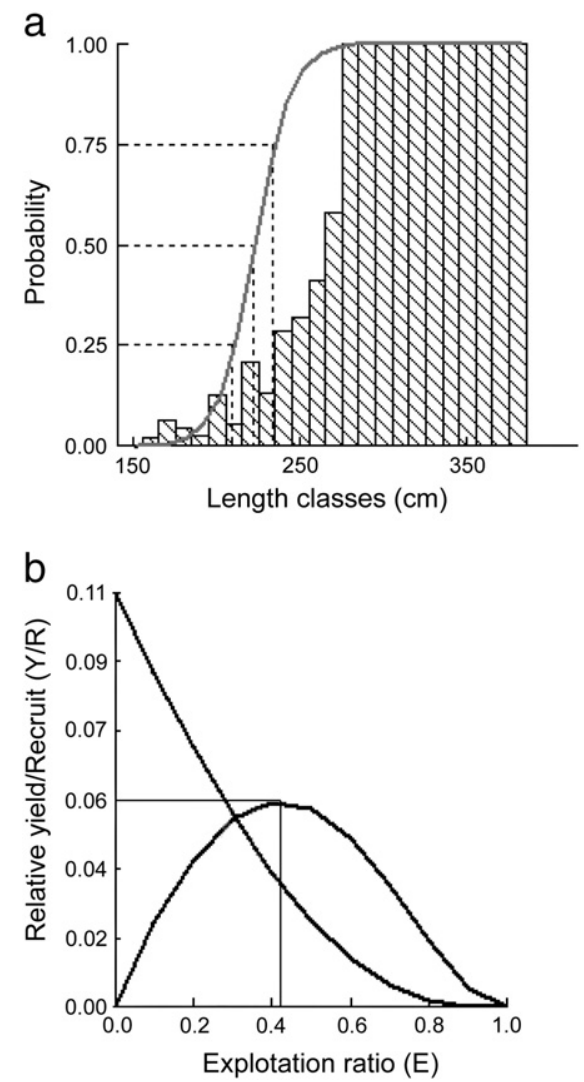

Fig. 7. a. Plot of probability of capture versus length in A. beckii. b. Yield per recruitment in A. beckii based on the Beverton and Holt (1964) model. Calculations by means of the FISAT software (reference). 
Apparently, A. beckii belongs to those gastropod species where growth in size has no inflexion point beyond one year of age, i.e. it can be described properly by the specialized von Bertalanffy function (see Picken, 1980; Santarelli and Gros, 1985; Appeldoorn, 1988; Prince et al., 1988; Tarr, 1995 for other examples). This is in contrast to other volutids that show a sigmoid size growth pattern, best described by the Gompertz model (e.g. Giménez et al., 2004; Bigatti et al., 2007) or the single logistic model (e.g. Cledón et al., 2005). Thus all standard fishery analysis that is based on the von Bertalanffy model, such as virtual population analysis, can be applied to A. beckii.

\subsection{Production, mortality and exploitation}

Our size-frenquency distribution is based on data collected from commercial catches with $42 \times 42 \mathrm{~mm}$ mesh size, therefore our sample efficiency is $<100 \%$ in smaller individuals. This is clearly indicated by the size-converted catch curve, where individuals smaller than 11 years of age are under-represented. Therefore, estimates of production and productivity based on this distribution would underestimate true population values distinctly. The estimated fishing mortality of $0.129 \mathrm{y}^{-1}$ appears to be fairly high for such a long lived species, and consequently the current exploitation rate of 0.614 is much beyond the optimum rate of 0.427 (Fig. 6). These findings indicate that the current exploitation regime exerts a much to high fishing pressure and will be unsustainable in the long run.

The ecological significance of $A$. beckii in the Mar del Plata subtidal water ecosystem is defined by its trophic position. This species preys on Zidona dufresnei (Arrighetti, 2009) and probably on other gastropods and bivalves (Weaver and du Pont, 1970), positioning it among the top benthic predators in the food web. The current exploitation level may cause irrevocable changes in this food web.

We fear that without a proper management approach - including minimum size, no-catch periods and no-catch areas - this economically valuable and ecologically important species will be reduced to insignificant levels in the Mar del Plata area within a short period of time.

\section{Acknowledgment}

This study was supported by the German Academic Exchange Service (DAAD) and the Malacological Society of London Research Grant. We are grateful to Kerstin Beyer for technical support. Part of this work was financed by the projects CONICET PIP 2788 and UBACyT X171.

\section{References}

Anderson, T.F., Arthur, M.A., 1983. Stable isotopes of oxygen and carbon and their application to sedimentologic and paleoenvironmental problems. Stable Isotopes in Sedimentary Geology, SEPM Short Course No 10, pp. 111-155.

Allen, K.R., 1971. Relation between production and biomass. J. Fish. Res. Board Can. 28, $1537-1581$.

Appeldoorn, R.S., 1988. Age determination, growth, mortality and age of first reproduction in adult queen conch, Strombus gigas L., off Puerto Rico. Fish. Res. 6, 363-378.

Arrighetti, F., 2009. Reproduction, ultrastructure and growth of the giant snail Adelomelon beckii (Broderip 1836) off Mar del Plata, Argentina. PhD Thesis. Universidad de Buenos Aires, Argentina. 185 pp.

Arrighetti, F., Giménez, J., 2010. Ultrastructure of euspermatozoa and paraspermatozoa in the marine gastropod Adelomelon beckii (Volutidae). Helgol. Mar. Res. 64, 143-148.
Arrighetti, F., Penchaszadeh, P.E., 2010a. Gametogenesis, seasonal reproduction and imposex of the edible giant marine snail Adelomelon beckii (Neogastropoda: Volutidae) in Mar del Plata, Argentina. Aquat. Biol 9, 63-75.

Arrighetti, F., Penchaszadeh, P.E., 2010b. Size and age at first maturity of the edible giant snail Adelomelon beckii (Neogastropoda: Volutidae) from Mar del Plata, Argentina. Malacologia 53 (1) xx-Xx.

Beverton, R.J.H., Holt, S.J., 1964. Manual of methods for fish stock assessment. Part 2. Tables of yield functions. FAO Fish. Tech. Pap. 3867 pp.

Bigatti, G., Penchaszadeh, P.E., Cledón, M., 2007. Age and growth in Odontocymbiola magellanica (Gastropoda: Volutidae) from Golfo Nuevo, Patagonia, Argentina. Mar. Biol. 150, 1199-1204.

Brey, T., 1999. Growth performance and mortality in aquatic benthic invertebrates. Adv. Mar. Biol. 35, 153-223.

Brey, T., 2001. Population dynamics in benthic invertebrates. A virtual handbook. : Version 01.2http://www.thomas-brey.de/science/virtualhandbook. Available on.

Cledón, M., Brey, T., Penchaszadeh, P.E., Arntz, W., 2005. Individual growth and somatic production in Adelomelon brasiliana (Gastropoda; Volutidae) off Argentina. Mar. Biol. 147, 447-452.

Craig, H., 1965. The measurement of oxygen isotope paleotemperatures. In: Tongiori, E. (Ed.), 2nd Conference on Stable Isotopes in Oceanographic Studies and Paleotemperatures. Consiglio Naz. Delle Ricerche, Speleto, Italy, pp. 161-182.

De Jesús-Navarrete, A., 2001. Growth of the queen conch Strombus gigas (Gastropoda: Strombidae) cultured in four environments of Quintana Roo, Mexico. Rev. Biol. Trop. 49, 85-91.

Epstein, S., Lowenstam, H.A., 1953. Temperature shell-growth relation of recent and interglacial Pleistocne shoal-water biota from Bermuda. J. Geol. 61, 424-438.

Epstein, S., Buchsbaum, R., Lowenstam, H.A., Urey, H.C., 1953. Revised carbonate-water isotopic temperature scale. Geol. Soc. Am. Bull. 64, 1315-1326.

Giménez, J., Brey, T., Mackensen, A., Penchaszadeh, P.E., 2004. Age, growth and mortality of the prosobranch snail Zidona dufresnei (Donovan, 1823) in the Mar del Plata area, SW Atlantic Ocean. Mar. Biol. 145, 707-712.

Giménez, J., Arrighetti, F., Teso, V., Hermida, G., Zabala, S., Penchaszadeh, P.E., 2009. Sperm morphology of two marine neogastropods from the southwestern Atlantic Ocean (Mollusca: Caenogastropoda). Nautilus 123, 166-171.

Guerrero, R.A., Piola, A.R., 1997. Water masses in the continental shelf. The Argentine sea and its fisheries resources. 1. Historical View of the Exploratory Cruises and the Environmental Characteristics of the Western South Atlantic Ocean. INIDEP, Mar del Plata, pp. 107-118.

Kideys, A.E., 1996. Determination of age and growth of Buccinum undatum L. (Gastropoda) off Douglas, Isle of Man. Helgol. Meeresunters. 50, 353-368.

LeGrande, A.N., Schmidt, G.A., 2006. Global gridded data set of the oxygen isotopic composition in seawater. Geophys. Res. Lett. 33, L12604.

Moreau, J., Bambino, C. Pauly, D., 1986. A comparison of four indices of overall fish growth performance, based on 100 tilapia populations (Fam. Cichlidae). In: Maclean, J.L., Dizon, L.B., Hosillos, L.V. (Eds.), The First Asian Fisheries Forum. Asian Fisheries Society, Manila, Philippines, pp. 201-206.

Pauly, D., 1984a. Length-converted catch curves: a powerful tool for fisheries in the tropics (part II). Fishbyte 2, 17-19.

Pauly, D., 1984b. Length-converted catch curves: a powerful tool for fisheries in the tropics (part III). Fishbyte 2, 8-10.

Pauly, D., Moreau, J., Gayanilo, F., 1994. A new method for comparing the growth performance of fishes, applied to wild and farmed Tilapias. In: Pullin, R.S.V., Lazard, J., Legendre, M., Amon Kothias, J.B., Pauly, D. (Eds.), The third international symposium on tilapia in aquaculture. ICLARM Conf. Proc. 41.

Picken, G.B., 1980. The distribution, growth, and reproduction of the Antarctic limpet Nacella (Patinigera) concinna (Strebel, 1908). J. Exp. Mar. Biol. Ecol. 42, 71-85.

Prince, J.D., Sellers, T.L., Ford, W.B., Talbot, S.R., 1988. Recruitment, growth. mortality and population structure in a southern Australian population of Haliotis rubra (Mollusca: Gastropoda). Mar. Biol. 100, 75-82.

Rabí, M., Maraví, C., 1997. Growth curves and specific growth rate of Concholepas concholepas (Bruguie` re, 1789) (Gastropoda: Muricidae) in culture experiments. Sci. Mar. 61, 49-53.

Salzwedel, H., 1980. Energy budgets for two populations of the bivalve Tellina fabula in the German Bight. Veröff. Inst. Meeresforsch. Bremerh. 18, 257-287.

Santarelli, L., Gros, P., 1985. Détermination de l'age et de la croissance de Buccinum undatum L. (Gasteropoda: Prosobranchia) à l'aide des isotopes stables de la coquille et de l'ornamentation operculaire. Oceanol. Acta 8, 221-229.

Shepherd, S.A., Hearn, W.S., 1983. Studies on Southern Australian abalone (genus Haliotis). IV. Growth H. laevigata H. ruber. Aust. J. Mar. Freshwater Res. 34, 461-475.

Tarr, R.J.Q., 1995. Growth and movement of the South African abalone Haliotis midae; a reassessment. Mar. Freshwater Res. 46, 583-590.

Weaver, C.S., du Pont, J.E., 1970. Living Volutes. A Monograph of the Recent Volutidae of the World. Delaware Museum of Natural History, Greenville, Del, pp. 1-375. 